\title{
Histone H1.1
}

National Cancer Institute

\section{Source}

National Cancer Institute. Histone H1.1. NCI Thesaurus. Code C126425.

Histone H1.1 (215 aa, $22 \mathrm{kDa}$ ) is encoded by the human H1-1 gene. This protein is involved in both DNA binding and chromatin compaction into higher order structures. 